\title{
Kreativitas Siswa dalam Menyelesaikan Soal Cerita Matematika di Masa Pandemi Pada Materi Persamaan Linear Dua Variabel
}

\author{
Arum Dwi Rahmawati \\ Pendidikan Matematika, STKIP Modern Ngawi, arum.dr21@gmail.com
}

\begin{abstract}
Abstrak
Penelitian ini bertujuan mengetahui kreativitas siswa SMP dalam menyelesaikan soal cerita berkaitan dengan sistem persamaan linear dua variabel, yang meliputi langkah memahami masalah, merencanakan pemecahan, menyelesaikan masalah sesuai langkah kedua dan memeriksa kembali hasil dari yang diperoleh. Subyek penelitian adalah enam siswa kelas VIIIB SMP Negeri 3 Ngrambe. Pengambilan subyek berdasarkan tingkat prestasi belajar matematika siswa yaitu dua siswa berkemampuan tinggi, dua siswa berkemampuan sedang dan dua siswa berkemampuan rendah. Teknik pengumpulan data dilakukan dengan metode tes dan wawancara. Hasil penelitian ini adalah (1) Siswa kriteria tinggi menunjukkan bahwa siswa tersebut berkecenderungan memiliki profil kreativitas yang baik dalam menguraikan jawaban secara terperinci sesuai prosedur yang runtut, tepat dan benar dalam menyelesaikan soal cerita, (2) Siswa kriteria sedang menunjukkan bahwa siswa tersebut berkecenderungan memiliki profil kreativitas yang cukup dalam menguraikan jawaban secara terperinci yaitu menyelesaikan soal cerita dengan prosedur yang runtut tetapi kurang tepat, (3) Siswa kriteria rendah menunjukkan bahwa siswa tersebut berkecenderungan memiliki profil kreativitas yang kurang yaitu tidak dapat menyelesaikan soal cerita dengan prosedur yang benar sesuai langkahlangkah penyelesaian masalah.
\end{abstract}

Kata Kunci: kreativitas, soal, cerita, persamaan, linear

\section{PENDAHULUAN}

Pendidikan merupakan salah satu wahana pengembangan siswa. Melalui pendidikan, siswa dapat mengembangkan pengetahuan dan keterampilan. Selain itu, dengan pendidikan siswa akan belajar berpikir untuk menyelesaikan masalah, membuat keputusan serta mencari pemahaman terhadap sesuatu. Dalam aktivitas keseharian untuk dapat bertahan hidup pada suatu keadaan yang selalu berubah dan kompetitif diperlukan kemampuan untuk mengolah, memilih dan mengelola informasi. Kemampuan ini membutuhkan pemikiran kritis, sistemmatis, logis dan kreatif serta mempunyai kemauan bekerja sama yang efektif.

Pembelajaran matematika merupakan salah satu cara pengembangan kemampuan berpikir siswa. Hal ini dikarenakan matematika memiliki struktur dan keterkaitan yang kuat dan jelas antar konsepnya. Matematika juga merupakan ilmu dasar yang digunakan sangat luas dan berkaitan dengan ilmu pengetahuan lainnya. Seperti ilmu pengetahuan lainnya matematika memiliki aspek kreatif dan juga aspek terapan atau praktik. Pembelajaran matematika diberikan kepada semua siswa mulai dari sekolah dasar hingga perguruan tinggi untuk membekali siswa dengan kemampuan berpikir logis, analitis, sistematis, kritis dan kreatif serta kemampuan bekerja sama.

Pada mata pelajaran matematika, masalah keseharian disajikan dalam bentuk soal cerita. Menyelesaikan soal cerita yang merupakan masalah matematika memang bukan hal yang mudah, dibutuhkan pemahaman, penalaran dan pemikiran kreatif untuk melakukan tindakan 
penyelesaian. Melalui pembelajaran matematika yang melibatkan imajinasi, intuisi dan penemuan dapat mengembangkan aktivitas kreatif siswa meliputi pemikiran divergen, orisinil, keingintahuan, membuat prediksi dan dugaan serta mencoba-coba. Keingintahuan siswa untuk melakukan penyelidikan dapat membantu mengembangkan kreativitas dan keterampilan bermatematika.

Untuk itu dalam bidang pendidikan, pengembangan kreativitas sangat dibutuhkan guna mendukung kelangsungan hidup dalam menghadapi tantangan global. Kreativitas merupakan hal yang sangat penting dalam pembelajaran. Jika diamati pembelajaran yang dilakukan oleh sebagian besar guru lebih menekankan pada ranah kognitif. Pembelajaran yang demikian menuntut siswa untuk menerima dan menghafal apa yang dianggap penting oleh guru. Demikian itu justru menghambat aktivitas dan kreativitas belajar siswa. Padahal dalam implementasi kurikulum KTSP guru dituntut untuk menciptakan suasana belajar yang kondusif, yang memungkinkan siswa dapat mengembangkan aktivitas dan kreativitaas belajarnya secara optimal, sesuai kemampuannya masing-masing.

Kondisi belajar itu antara lain dengan teknik kerja kelompok kecil dan penugasan. Eric Jansen (2008:288) menyebutkan "Berpikir adalah sebuah proses dari otak yang mengakses representasi sebelumnya untuk memahami atau menciptakan sebuah model baru jika memang belum ada".

Bimo Walgito (2004:177) mengungkapkan "Berpikir itu merupakan proses kognitif yang berlangsung antar stimulus dan respons". Santrock (terjemahan Diana Angelica, 2009:7) mendefinisikan berpikir sebagai berikut: "Berpikir melibatkan kegiatan memanipulasi dan mentransformasi informasi dalam memori”.

Berdasarkan pengertian di atas, berpikir dapat diartikan sebagai suatu aktivitas kognitif yang berwujud mengolah dan memanipulasi informasi yang diperoleh dari lingkungan dengan menggunakan pegertian-pengertian yang telah dipelajari untuk pemecahan masalah. Pengertian-pengertian itu merupakan materi yang bisa berupa kata-kata, simbol, gambar atau grafik.

Syamsu dan Juntika (2010:246) mengungkapkan pendapatnya mengenai kreativitas yang diartikan sebagai kemampuan untuk menciptakan suatu produk baru, atau kemampuan untuk memberikan gagasangagasan baru dan menerapkannya dalam pemecahan masalah.

"Kreativitas adalah kemampuan untuk berpikir mengenai sesuatu, dalam cara yang baru dan tidak biasa serta memikirkan solusisolusi unik terhadap masalah" (Santrock, terjemahan Diana Angelica, 2009:21).

"Kreativitas, seperti pemecahan masalah, adalah salah satu bentuk transfer, karena hal tersebut melibatkan pengaplikasian pengetahuan dan keterampilan yang telah diketahui sebelumnya pada situasi yang baru" (Ormrod, terjemahan Wahyu Indianti, 2008:405).

Robert Solso (terjemahan Kristianto dan Mikael, 2007:444-445) mengatakan "Kreativitas adalah suatu aktivitas kognitif yang menghasilkan suatu pandangan yang baru mengenai suatu bentuk permasalahan dan tidak dibatasi pada hasil yang pragmatis (selalu dipandang menurut kegunaannya)".

Ausebel (dalam Hamalik, 2004:179) mengemukakan kreativitas sebagai berikut:

"Creative achievement ... reflect a rare capacity for developing insight, sensitivities, and appreciations in a circumscribed content area of intellectual or artistic activity".

Rumusan itu mengatakan bahwa orang kreatif adalah orang yang memiliki kemampuan kapasitas (pemahaman, sensitivitas, dan apresiasi), yang melebihi dari seseorang yang intelegen. 
Tidak jauh berbeda dengan Ausebel, Piaget (dalam Mulyasa, 2008:59) mengatakan sebagai berikut ini:

"The principal goal of education is to create man who are capable of doing new thing, not simply of repeating what other generations have done-man who are creative, inventive, and discoverers".

Pernyataan itu menjelaskan bahwa tugas utama pendidikan adalah menciptakan orang-orang yang mampu melakukan sesuatu yang baru, tidak hanya mengulang apa yang telah dikerjakan oleh generasi lain. Dengan kata lain, dapat dikatakan pendidikan akan berhasil apabila dapat melahirkan sejumlah orang kreatif.

Berdasarkan pendapat para ahli di atas, maka kreativitas dapat dirumuskan sebagai suatu proses aktivitas kognitif yang bertujuan menghasilkan gagasan-gagasan baru dan menerapkannya dalam pemecahan masalah.

Unsur-unsur Kreativitas Menurut Guilfould (dalam Utami Munandar, 2009:10-11) unsurunsur berpikir kreatif yang berhubungan dengan kognitif meliputi kelancaran, keluwesan, kelenturan (fleksibilitas), dan orisinalitas dalam berpikir. Unsur-unsur kreativitas di atas dijelaskan sebagai berikut. Kelancaran berpikir (fluency of thinking), yaitu kemampuan untuk menghasilkan banyak gagasan/jawaban yang relevan secara cepat. Dalam kelancaran berpikir yang ditekankan adalah kuantitas bukan kualitas. Keluwesan berpikir (flexibility), yaitu kemampuan untuk menghasilkan sejumlah gagasan/jawaban suatu pertanyaan yang bervariasi, melihat suatu masalah dari sudut pandang yang berbeda-beda dan menerapkan konsep dengan cara yang berbeda. Orang kreatif adalah orang yang luwes dalam berpikir. Mereka dengan mudah dapat meninggalkan cara berpikir lama dan menggantikannya dengan cara berpikir baru. a. Originalitas (originality), yaitu kemampuan untuk memberikan gagasan unik atau kemampuan untuk memberikan gagasan asli.

b. Elaborasi (elaboration), yaitu kemampuan dalam mengembangkan gagasan dan menambahkan atau memperinci detail-detail dari suatu objek, gagasan atau situasi sehingga menjadi lebih menarik.

Torrance mengemukakan bahwa ada empat karakteristik berpikir kreatif, sebagai sebuah proses yang melibatkan unsur-unsur kelancaran, keluwesan, orisinalitas dan elaborasi. Keempat karakteristik dari berpikir kreatif tersebut tersebut didefinisikan berikut:

a. Kelancaran yaitu kemampuan untuk menciptakan segudang ide/gagasan.

b. Keluwesan yaitu kemampuan untuk memandang sebuah masalah secara instan dari berbagai perspektif.

c. Orisinalitas yaitu mengacu pada keunikan dari respon yang diberikan. Orisinalitas ditunjukkan oleh sebuah respon yang tidak biasa, unik dan jarang terjadi. Elaborasi yaitu kemampuan untuk menguraikan sebuah obyek tertentu.

Berdasarkan pendapat para ahli di atas, dapat disimpulkan bahwa unsur-unsur kreativitas meliputi kemampuan berpikir berikut:

a. Kelancaran berpikir adalah kemampuan untuk memberikan banyak gagasan/ide yang relevan dalam penyelesaian masalah.

b. Keluwesan berpikir adalah kemampuan menghasilkan jawaban penyelesaian masalah yang bervariasi, melihat suatu masalah dari sudut pandang yang berbeda-beda dan menerapkan suatu konsep dengan cara yang berbeda.

c. Orisinalitas adalah kemampuan memberikan gagasan unik/baru dalam menjawab suatu pertanyaan.

d. Elaborasi adalah kemampuan mengembangkan gagasan dan kemampuan meguraikan gagasan secara terperinci. 
"Pemecahan masalah adalah suatu pemikiran yang terarah secara langsung untuk menemukan suatu solusi/jalan keluar untuk suatu masalah yang spesifik (Solso, terjemahan Kristianto dan Mikael, 2007:434)".

Hudojo (2005:125) menyatakan pemecahan masalah merupakan proses penerimaan masalah sebagai tantangan untuk menyelesaikan masalah tersebut. Santrock (terjemahan Diana Angelica, 2009:28) mendefinisikan bahwa "pemecahan masalah melibatkan penemuan sebuah cara yang sesuai untuk mencapai suatu tujuan".

Ormrod (terjemahan Wahyu Indianti 2008:393) menjelaskan bahwa "pemecahan masalah adalah menggunakan (yaitu mentrasfer) pengetahuan dan keterampilan yang sudah ada untuk menjawab pertanyaan yang belum terjawab atau situasi yang sulit". Adapun Polya (Budi Haryanto, 2011) mengartikan "pemecahan masalah sebagai satu usaha mencari jalan keluar dari satu kesulitan guna mencapai satu tujuan yang tidak begitu mudah untuk segera dicapai”.

Jadi pemecahan masalah adalah usaha seseorang untuk menyelesaikan permasalahan menggunakan pengetahuan, keterampilan serta pemahaman yang dimilikinya untuk mencapai tujuan atau jalan keluar.

Polya menjelaskan solusi soal pemecahan masalah ada empat tahap:

1. Memahami masalah, Pada langkah ini, siswa harus dapat menentukan dengan jeli apa sajakah data yang diketahui dan apa yang ditanyakan serta bagaimana syaratnya (hubungan antara yang ditanya dan yang diketahui dan apakah syarat tersebut sudah cukup untuk menentukan apa yang ditanyakan). Siswa dituntut membaca soal seksama sehingga memahami maksud soal dengan baik yang di dalamnya mengandung hal-hal apa yang diketahui, apa yang ditanyakan dan menuliskannya dengan simbol-simbol matematika. Karena keterbatasan memori yang dimiliki oleh siswa, maka hal-hal penting tersebut dicatat, dibuat tabel dan diagram/grafiknya.

2. Merencanakan pemecahan, Setelah memahami maksud soal maka untuk menjawab pertanyaan yang ditanyakan, siswa harus membuat rencana penyelesaian soal dengan mengumpulkan informasiinformasi atau data-data yang ada kemudian mengubah soal cerita ke dalam kalimat matematika.

3. Menyelesaikan masalah sesuai rencana langkah kedua

Rencana yang telah tersusun dalam kalimat matematika dapat digunakan untuk menyelesaikan soal cerita dalam usaha siswa menemukan penyelesaiannya dengan menggunakan rumus-rumus, konsep teorema dan pengetahuan lainnya yang telah dipelajari. Pada langkah kedua ini siswa harus yakin bahwa setiap langkah sudah benar.

4. Memeriksa kembali hasil yang diperoleh, Memeriksa kembali hasil yang diperoleh dilakukan untuk memastikan hasil pekerjaan dari tahap pertama sampai ketiga benar, maka siswa harus melakukan pengecekan ulang. Jika ada kesalahan siswa dapat segera memperbaikinya hingga menemukan solusi yang benar dan tepat. Langkah ini kurang diperhatikan oleh siswa, kebanyakan siswa hampir tidak pernah melakukan pengecekan padahal tahapan ini sangat menentukan ketepatan hasil pekerjaan dan meminimalisir kesalahan.

Berdasarkan pendapat Polya maka pendapat tersebut dijadikan sebagai acuan langkahlangkah pemecahan masalah terhadap deskriptor dan indikator.

Soal cerita adalah soal yang disajikan dalam bentuk cerita pendek. Cerita yang diungkapkan merupakan masalah kehidupan 
sehari-hari atau masalah lainnya (Abidin dalam Syamrilaode, 2010).

Sedangkan Haji (Syamrilaode, 2010) mengemukakan soal cerita merupakan modifikasi dari soal-soal hitungan yang berkaitan dengan kenyataan yang ada di lingkungan siswa. Dalam penyelesaian soal cerita siswa harus melakukan abstraksi yaitu mengubah permasalahan pada soal cerita menjadi kalimat matematika dengan menuliskan apa yang diketahui, apa yang ditanya, dan membuat model. Kemudian dilanjutkan dengan melakukan komputasi yaitu menyelesaikan kalimat matematika dengan perhitungan dan diakhiri dengan menafsirkan yaitu mengembalikan jawaban model sebagai jawaban permasalahan.

Dapat disimpulkan bahwa menyelesaikan soal cerita pada dasarnya adalah menentukan penyelesaian dari permasalahan sesuai konsep atau teorema yang sesuai dengan langkahlangkah penyelesaian.

\section{METODE}

Jenis penelitian ini adalah penelitian kualitatif. Peneliti memilih pendekatan kualitatif sebab ingin meneliti individu yang nantinya hasil dari penelitian dideskripsikan secara rinci dalam bentuk teks. Sumber data dalam penelitian adalah subyek dari mana data diperoleh yaitu siswa. Datanya diperoleh dari hasil wawancara dengan siswa yang diberi tes.

Dalam penelitian ini tes disusun oleh peneliti sendiri, dengan terlebih dahulu dikonsultasikan dengan dosen pembimbing sehingga didapatkan kesesuaian dengan materi yang akan diujikan. Tes yang diberikan kepada siswa berupa tes uraian, karena dalam menjawab soal cerita siswa harus menjawab soal secara terurai dan diperlukan pemahaman terhadap materi yang diujikan.

"Tes uraian adalah pertanyaan yang menuntut siswa menjawabnya dalam bentuk menguraikan, menjelaskan, mendiskusikan, membandingkan, memberikan alasan dan bentuk lain yang sejenis dengan tuntutan pertanyaan dengan menggunakan kata-kata dan bahasa sendiri (Nana Sudjana, 2010:35)".

Tes digunakan untuk mendapatkan informasi tentang kemampuan siswa dalam memecahkan masalah matematika bentuk soal cerita pada materi sistem persamaan linear dua variabel serta untuk mengetahui kreativitas siswa dalam menyelesaikan soal cerita.

Dalam penelitian ini, digunakan wawancara tak terstruktur atau sering disebut sebagai wawancara mendalam. Wawancara tak terstruktur adalah wawancara yang bersifat bebas, peneliti tidak menggunakan pedoman wawancara yang telah tersusun secara sistematis dan lengkap untuk pengumpulan datanya (Sugiyono, 2007:233).

Adapun langkah-langkah yang dilakukan peneliti dalam mengumpulkan data melalui wawancara yaitu dimuali Membuat pedoman wawancara tak terstruktur. Pedoman wawancara tak terstruktur yang digunakan hanya berupa garis-garis besar permasalahan yang akan ditanyakan.kemudian wawancara dilakukan secara terbuka antara siswa dan pewawancara. Semua yang dikemukakan siswa dijamin keasliannya dan tidak akan mempengaruhi nilai matematika. Dalam wawancara ini diperlukan kejujuran yang sangat diperlukan demi kemajuan proses belajar matematika khususnya bagi kelas VIII dan demi keberhasilan penelitian ini. Wawancara dilaksanakan terhadap masing-masing siswa secara terpisah dan butir pertanyaan dikembangkan dari hasil jawaban tes yang dilakukan oleh siswa. Menganalisis hasil wawancara sehingga diperoleh hal-hal yang berkaitan dengan kreativitas siswa dalam menyelesaikan soal cerita matematika.

Wawancara dilaksanakan pada saat jam istirahat agar tidak mengganggu kegiatan belajar mengajar pada bidang studi yang lain. Selama pelaksanaan wawancara, peneliti 
menggunakan catatan dan hasil pekerjaan siswa dalam menyelesaikan soal tes. Masing-masing responden diwawancarai secara terpisah agar data yang diperoleh terjamin keasliannya dan tidak saling mempengaruhi.

\section{HASIL DAN PEMBAHASAN}

Berdasarkan hasil penelitian dari tes dan wawancara, peneliti membuat tabel pengkodean kreativitas siswa dalam menyelesaikan soal cerita sebagai berikut.

\begin{tabular}{|c|c|c|c|c|c|c|c|c|c|c|c|c|c|}
\hline \multirow{2}{*}{\begin{tabular}{|l}
$\tilde{\tilde{U}}$ \\
$\tilde{\Xi}$ \\
$\bar{\alpha}$ \\
$\frac{\tilde{\alpha}}{\pi}$
\end{tabular}} & \multicolumn{13}{|c|}{ Analisis Subyek Hasil Tes dan Wawancara } \\
\hline & - & $N$ & $\omega$ & $\rightarrow$ & ur & $a$ & $\checkmark$ & $\infty$ & 0 & $\widetilde{\sigma}$ & Е & $\vec{N}$ & $\vec{\omega}$ \\
\hline 1 & $\begin{array}{c}\mathrm{A} 1 \\
\mathrm{a}\end{array}$ & $\begin{array}{c}\text { B1 } \\
\text { b }\end{array}$ & - & $\begin{array}{c}\text { B2 } \\
b\end{array}$ & - & $\begin{array}{c}\text { B3 } \\
\text { b }\end{array}$ & - & $\begin{array}{c}\text { C1 } \\
\text { b }\end{array}$ & $\begin{array}{c}\text { D1 } \\
\text { b }\end{array}$ & - & $\begin{array}{c}\text { D2 } \\
\mathrm{a}\end{array}$ & - & - \\
\hline 2 & $\begin{array}{c}\mathrm{A} 1 \\
\mathrm{a}\end{array}$ & $\begin{array}{c}\text { B1 } \\
\text { b }\end{array}$ & - & $\begin{array}{c}\text { B2 } \\
\text { b }\end{array}$ & - & $\begin{array}{c}\text { B3 } \\
\text { b }\end{array}$ & - & $\begin{array}{c}\mathrm{C} 1 \\
\mathrm{~b}\end{array}$ & $\begin{array}{c}\mathrm{D} 1 \\
\mathrm{~b}\end{array}$ & - & $\begin{array}{c}\mathrm{D} 2 \\
\mathrm{a}\end{array}$ & - & - \\
\hline 3 & $\begin{array}{c}\mathrm{A} 1 \\
\mathrm{a}\end{array}$ & $\begin{array}{c}\mathrm{B} 1 \\
\mathrm{~b}\end{array}$ & - & $\begin{array}{c}\mathrm{B} 2 \\
\mathrm{~b}\end{array}$ & - & $\begin{array}{c}\text { B3 } \\
\text { b }\end{array}$ & - & $\begin{array}{c}\mathrm{C} 1 \\
\mathrm{~b}\end{array}$ & $\begin{array}{c}\mathrm{D} 1 \\
\mathrm{~b}\end{array}$ & - & - & $\begin{array}{c}\mathrm{D} 2 \\
\mathrm{~b}\end{array}$ & - \\
\hline 4 & $\begin{array}{c}\mathrm{A} 1 \\
\mathrm{a}\end{array}$ & - & $\begin{array}{c}\text { B1 } \\
\text { c }\end{array}$ & $\begin{array}{c}\text { B2 } \\
\text { b }\end{array}$ & - & $\begin{array}{c}\text { B3 } \\
\text { b }\end{array}$ & - & $\begin{array}{c}\text { C1 } \\
\text { b }\end{array}$ & - & $\begin{array}{c}\text { D1 } \\
\text { c }\end{array}$ & - & - & $\begin{array}{c}\text { D2 } \\
\text { c }\end{array}$ \\
\hline 5 & $\begin{array}{c}\text { A1 } \\
\text { a }\end{array}$ & - & $\begin{array}{c}\text { B1 } \\
\text { c }\end{array}$ & $\begin{array}{c}\mathrm{B} 2 \\
\mathrm{~b}\end{array}$ & - & $\begin{array}{c}\text { B3 } \\
\text { b }\end{array}$ & - & $\begin{array}{c}\mathrm{C} 1 \\
\mathrm{~b}\end{array}$ & - & $\begin{array}{c}\mathrm{D} 1 \\
\mathrm{c}\end{array}$ & - & - & $\begin{array}{c}\mathrm{D} 2 \\
\mathrm{c}\end{array}$ \\
\hline 6 & $\begin{array}{c}\mathrm{A} 1 \\
\mathrm{a}\end{array}$ & - & $\begin{array}{c}\mathrm{B} 1 \\
\mathrm{c}\end{array}$ & - & $\begin{array}{c}\text { B2 } \\
\text { c }\end{array}$ & - & $\begin{array}{c}\text { B3 } \\
\text { c }\end{array}$ & - & - & $\begin{array}{c}\mathrm{D} 1 \\
\mathrm{c}\end{array}$ & - & - & $\begin{array}{c}\mathrm{D} 2 \\
\mathrm{c}\end{array}$ \\
\hline
\end{tabular}

Berdasarkan hasil analisis tes tulis dan wawancara tabel $5.1 \mathrm{di}$ atas, peneliti dapat menjelaskan analisis sebagai berikut.

1. Berdasarkan hasil analisis data tes tulis dan wawancara yang termuat di tabel 5.1 di atas dapat dilihat di kolom 1 ada persamaan kode pada subyek kategori tinggi, sedang dan rendah memiliki kecenderungan kelancaran berpikir dengan deskriptor memberikan banyak gagasan/ide yang relevan dalam penyelesaian masalah dengan kode A1a yaitu kategori baik yang berarti dapat memberikan lebih dari satu gagasan/ide yang relevan dalam penyelesaian masalah.

2. Berdasarkan hasil analisis data tes tulis dan wawancara yang termuat di tabel 5.1 di atas dapat dilihat di kolom 2 ada persamaan kode pada subyek kategori tinggi dan sedang memiliki kecenderungan keluwesan berpikir dengan deskriptor menghasilkan jawaban penyelesaian masalah yang bervariasi dengan kode B1b yaitu kategori cukup yang berarti dapat memberikan sebuah jawaban dalam penyelesaian masalah.

3. Berdasarkan hasil analisis data tes tulis dan wawancara yang termuat di tabel 5.1 di atas dapat dilihat di kolom 3 ada persamaan kode pada subyek kategori sedang dan rendah memiliki kecenderungan keluwesan berpikir dengan deskriptor menghasilkan jawaban penyelesaian masalah yang bervariasi dengan kode B1c yaitu kategori kurang yang berarti tidak dapat memberikan sebuah jawaban penyelesaian masalah.

4. Berdasarkan hasil analisis data tes tulis dan wawancara yang termuat di tabel 5.1 di atas dapat dilihat di kolom 4 ada persamaan kode pada subyek kategori tinggi, sedang dan rendah memiliki kecenderungan keluwesan berpikir dengan deskriptor melihat suatu masalah dari sudut pandang yang berbeda dengan kode $\mathbf{B 2 b}$ yaitu kategori cukup yang berarti dapat mendefinisikan kembali suatu masalah dengan sebuah cara yang berbeda.

5. Berdasarkan hasil analisis data tes tulis dan wawancara yang termuat di tabel 5.1 di atas dapat dilihat di kolom 6 ada persamaan pada subyek kategori tinggi, sedang dan rendah memiliki kecenderungan keluwesan berpikir dengan deskriptor menerapkan suatu konsep dengan cara yang berbeda dengan kode B3b yaitu kategori cukup yang berarti dapat menerapkan sebuah konsep dengan cara yang berbeda dalam penyelesaian masalah.

6. Berdasarkan hasil analisis data tes tulis dan wawancara yang termuat di tabel 5.1 di atas dapat dilihat di kolom 8 subyek kategori 
tinggi, sedang dan rendah memiliki kecenderungan orisinalitas dengan deskriptor memberikan gagasan unik/baru dalam menyelesaikan masalah dengan kode C1b yaitu kategori cukup yang berarti dapat memberikan sebuah alasan terhadap penyelesaian yang digunakan.

7. Berdasarkan hasil analisis data tes tulis dan wawancara yang termuat di tabel 5.1 di atas dapat dilihat di kolom 9 ada persamaan pada subyek kategori tinggi dan sedang memiliki kecenderungan elaborasi dengan deskriptor mengembangkan gagasan dengan kode D1b yaitu kategori cukup yang berarti dapat mengkombinasikan sebuah strategi penyelesaian masalah.

8. Berdasarkan hasil analisis data tes tulis dan wawancara yang termuat di tabel 5.1 di atas dapat dilihat di kolom 10 ada persamaan pada subyek kategori sedang dan rendah memiliki kecenderungan elaborasi dengan deskriptor mengembangkan gagasan dengan kode D1c yaitu kategori kurang yang berarti tidak dapat mengkombinasikan strategi penyelesaian masalah.

9. Berdasarkan hasil analisis data tulis tes dan wawancara yang termuat di tabel 5.1 di atas dapat dilihat di kolom 11 subyek kategori tinggi memiliki kecenderungan elaborasi dengan deskriptor menguraikan gagasan/jawaban secara terperinci dengan kode D2a yaitu kategori baik yang berarti dapat menjelaskan gagasan/jawaban secara terperinci dan runtut dengan tepat.

10. Berdasarkan hasil analisis data tes tulis dan wawancara yang termuat di tabel $5.1 \mathrm{di}$ atas dapat dilihat di kolom 13 ada persamaan pada subyek kategori sedang dan rendah memiliki kecenderungan elaborasi dengan deskriptor mengembangkan gagasan dengan kode D2c yaitu kategori kurang yang berarti tidak dapat menjelaskan gagasan/jawaban secara terperinci dan runtut.

Berdasarkan sajian data analisis tes tulis dan wawancara tersebut, selanjutnya dilakukan penarikan simpulan tentang kemampuan pemecahan masalah soal cerita matematika pada materi sistem persamaan linear dua variabel yang terdiri dari 4 tahap langkah pemecahan masalah yaitu:

Tahap 1 Memahami masalah; Tahap 2: Merencanakan pemecahan masalah; Tahap 3 Menyelesaikan masalah sesuai rencana kedua; Tahap 4 Memeriksa kembali hasil yang diperoleh. Adapun sajian data dari 4 tahap langkah penyelesaian untuk masing-masing kelompok baik kelompok tinggi, sedang dan rendah dijelaskan di bawah ini sebagai berikut.

Tahap 1: Analisis profil kreativitas siswa pada langkah memahami masalah.

1. Pada tahap memahami masalah subyek kategori tinggi, sedang dan rendah dalam kelancaran berpikir dengan deskriptor memberikan banyak gagasan/jawaban yang relevan dalam penyelesaian masalah termasuk baik. Subyek dapat menuliskan yang diketahui dan ditanya sesuai permasalahan dalam soal.

2. Pada tahap memahami masalah subyek kategori tinggi, sedang dan rendah dalam keluwesan berpikir dengan deskriptor melihat suatu masalah dari sudut pandang yang berbeda termasuk cukup. Subyek dapat merumuskan masalah menggunakan variabel dan membentuk persamaanpersamaan linear dua variabelnya.

3. Pada tahap memahami masalaha subyek kategori tinggi, sedang dan rendah dalam keluwesan berpikir dengan deskriptor menerapkan suatu konsep dengan cara yang berbeda termasuk cukup. Subyek tidak dapat merumuskan masalah dari kalimat-kalimat dalam soal. 
4. Pada tahap memahami masalah subyek kategori tinggi, sedang dan rendah dalam orisinalitas dengan deskriptor memberikan gagasan unik/baru dalam menyelesaikan masalah termasuk cukup. Subyek dapat menerapkan konsep aljabar dan penyelesaian SPLDV metode eliminasi substitusi dengan benar.

5. Pada tahap memahami masalah subyek kategori tinggi dan sedang dalam elaborasi dengan descriptor mengembangkan gagasan termasuk cukup. Subyek menerapkan sebuah konsep dengan baik dalam penyelesaian masalah.

6. Pada tahap memahami masalah subyek kategori sedang dan rendah dalam elaborasi dengan deskriptor mengembangkan gagasan termasuk kurang. Subyek tidak dapat menerapkan konsep penyelesaian SPLDV dengan baik.

7. Pada tahap memahami masalah dalam elaborasi dengan deskriptor menguraikan gagasan/jawaban secara terperinci trmasuk baik. Subyek dapat menjelaskan penyelesaiannya sesuai langkahlangkahnya.

8. Pada tahap memahami masalah subyek kategori sedang dan rendah dalam elaborasi dengan deskriptor menguraikan gagasan/jawaban secara terperinci termasuk kurang. Subyek dapat menjelaskan penyelesainnya sesuai langkah-langkahnya.

Tahap 2: Analisis profil kreativitas siswa pada langkah merencanakan pemecahan masalah

1. Pada tahap merencanakan masalah subyek kategori tinggi, sedang dan rendah memiliki kecenderungan kelancaran berpikir baik dengan deskriptor memberikan banyak gagasan/ide yang relevan dalam penyelesaian masalah. Subyek dapat memberikan lebih dari satu gagasan/ide yang relevan dalam penyelesaian masalah untuk menuliskan yang diketahui dan ditanya.

2. Pada tahap merencanakan masalah subyek kategori tinggi dan sedang yaitu memiliki kecenderungan keluwesan berpikir cukup dengan deskriptor menghasilkan jawaban penyelesaian masalah yang bervariasi. Subyek dapat memberikan sebuah jawaban dalam penyelesaian masalah.

3. Pada tahap merencanakan masalah subyek kategori sedang dan rendah yaitu memiliki kecenderungan keluwesan berpikir kurang dengan deskriptor menghasilkan jawaban penyelesaian masalah yang bervariasi, subyek tidak dapat memberikan sebuah jawaban penyelesaian masalah.

4. Pada tahap menyelesaikan masalah subyek kategori tinggi, sedang dan rendah memiliki kecenderungan keluwesan berpikir cukup dengan deskriptor melihat suatu masalah dari sudut pandang yang berbeda. Subyek dapat mendefinisikan kembali suatu masalah dengan sebuah cara yang berbeda.

5. Pada tahap mnyelesaikan masalah subyek kategori tinggi, sedang dan rendah memiliki kecenderungan keluwesan berpikir cukup dengan deskriptor menerapkan suatu konsep dengan cara yang berbeda. Subyek tidak dapat mendefinisikan kembali suatu masalah dengan cara yang berbeda.

6. Pada tahap menyelesaikan masalah subyek kategori tinggi, sedang dan rendah memiliki kecenderungan orisinalitas cukup dengan deskriptor memberikan gagsan unuik/baru dalam menjawab suatu pertanyaan. Subyek dapat memberikan sebuah alasan terhadap cara penyelesaian yang digunakan.

7. Pada tahap menyelesaikan masalah subyek kategori tinggi dan sedang yaitu memiliki kecenderungan elaborasi cukup dengan deskriptor mengembangkan gagasan. 
Subyek dapat mengkombinasikan sebuah strategi dalam penyelesaian masalah yang relevan.

8. Pada tahap menyelesaaikan masalah subyek kategori sedang dan rendah yaitu memiliki kecenderungan elaborasi kurang dengan deskriptor mengembangkan gagasan. Subyek tidak dapat mengkombinasikan sebuah strategi dalam penyelesaian masalah yang relevan.

9. Pada tahap menyelesaikan masalah kategori tinggi memiliki kecenderungan elaborasi baik dengan deskriptor menguraikan gagasan/jawaban secara terperinci, runtut dan tepat. Subyek dapat menguraikan gagasan/jawaban secara terperinci, runtut dan tepat.

10. Pada tahap menyelesaikan masalah subyek kategori sedang dan rendah memiliki kecenderungan elaborasi kurang dengan deskriptor menguraikan gagasan/jawaban secara terperinci, runtut dan tepat. Subyek tidak dapat menguraikan gagasan/jawaban secara terperinci dan runtut.

Tahap 3: Analisis profil kreatif siswa pada langkah menyelesaikan masalah sesuai rencana kedua.

1. Pada tahap menyelesaikan masalah subyek kategori tinggi, sedang dan rendah memiliki kecenderungan kelancaran berpikir baik dengan deskriptor memberikan banyak gagasan/ide yang relevan dalam penyelesaian masalah. Subyek dapat memberikan lebih dari satu gagasan/ide yang relevan dalam penyelesaian masalah untuk menuliskan yang diketahui dan ditanya.

2. Pada tahap menyelesaikan masalah subyek kategori tinggi dan sedang memiliki kecenderungan keluwesan berpikir cukup dengan deskriptor menghasilkan jawaban penyelesaian masalah yang bervariasi.
Subyek dapat memberikan sebuah jawaban dalam penyelesaian masalah.

3. Pada tahap menyelesaikan masalah subyek kategori sedang dan rendah yaitu memiliki kecenderungan keluwesan berpikir kurang dengan deskriptor menghasilkan jawaban penyelesaian masalah yang bervariasi, subyek tidak dapat memberikan sebuah jawaban penyelesaian masalah.

4. Pada tahap menyelesaikan masalah subyek kategori tinggi, sedang dan rendah memiliki kecenderungan keluwesan berpikir cukup dengan deskriptor melihat suatu masalah dari sudut pandang yang berbeda. Subyek dapat mendefinisikan kembali suatu masalah dengan sebuah cara yang berbeda.

5. Pada tahap mnyelesaikan masalah subyek kategori tinggi, sedang dan rendah memiliki kecenderungan keluwesan berpikir cukup dengan deskriptor menerapkan suatu konsep dengan cara yang berbeda. Subyek tidak dapat mendefinisikan kembali suatu masalah dengan cara yang berbeda.

6. Pada tahap menyelesaikan masalah subyek kategori tinggi, sedang dan rendah memiliki kecenderungan orisinalitas cukup dengan deskriptor memberikan gagsan unuik/baru dalam menjawab suatu pertanyaan. Subyek dapat memberikan sebuah alasan terhadap cara penyelesaian yang digunakan.

7. Pada tahap menyelesaikan masalah subyek kategori tinggi dan sedang memiliki kecenderungan elaborasi cukup dengan deskriptor mengembangkan gagasan. Subyek dapat mengkombinasikan sebuah strategi dalam penyelesaian masalah yang relevan.

8. Pada tahap menyelesaaikan masalah subyek kategori sedang dan rendah memiliki kecenderungan elaborasi kurang dalam deskriptor mengembangkan gagasan. 
Subyek tidak dapat mengkombinasikan sebuah strategi dalam penyelesaian masalah yang relevan.

9. Pada tahap menyelesaikan masalah subyek kategori tinggi memiliki kecenderungan elaborasi baik dalam deskriptor menguraikan gagasan/jawaban secara terperinci, runtut dan tepat. Subyek dapat menguraikan gagasan/jawaban secara terperinci, runtut dan tepat.

10. Pada tahap menyelesaikan masalah subyek kategori sedang dan rendah memiliki kecenderungan elaborasi kurang dengan deskriptor menguraikan gagasan/jawaban secara terperinci, runtut dan tepat. Subyek tidak dapat menguraikan gagasan/jawaban secara terperinci dan runtut.

Tahap 4: Analisis profil kreativitas siswa pada langkah memeriksa kembali hasil yang diperoleh.

1. Pada tahap memeriksa kembali subyek kategori tinggi dan sedang memiliki kecenderungan keluwesan berpikir cukup dengan deskriptor menghasilkan jawaban penyelesaian masalah yang bervariasi. Subyek dapat memberikan sebuah jawaban dalam penyelesaian masalah.

2. Pada tahap memeriksa kembali subyek kategori sedang dan rendah memiliki kecenderungan keluwesan berpikir kurang dengan deskriptor menghasilkan jawaban penyelesaian masalah yang bervariasi, subyek tidak dapat memberikan sebuah jawaban penyelesaian masalah.

3. Pada tahap memeriksa kembali subyek kategori tinggi, sedang dan rendah memiliki kecenderungan orisinalitas cukup dengan deskriptor memberikan gagsan unuik/baru dalam menjawab suatu pertanyaan. Subyek dapat memberikan sebuah alasan terhadap cara penyelesaian yang digunakan.
4. Pada tahap memeriksa kembali subyek kategori tinggi dan sedang kategori memiliki kecenderungan elaborasi cukup dengan deskriptor mengembangkan gagasan. Subyek dapat mengkombinasikan sebuah strategi dalam penyelesaian masalah yang relevan.

5. Pada tahap memeriksa kembali subyek kategori sedang dan rendah memiliki kecenderungan elaborasi kurang dengan deskriptor mengembangkan gagasan. Subyek tidak dapat mengkombinasikan strategi dalam penyelesaian masalah yang relevan.

6. Pada tahap menyelesaikan masalah kategori tinggi memiliki kecenderungan kreativitas baik dalam elaborasi dengan deskriptor menguraikan gagasan/jawaban secara terperinci. Subyek dapat mnguraikan gagasan/jawaban secara terperinci dan runtut dengan tepat.

7. Pada tahap memeriksa kembali subyek kategori sedang dan rendah kategori memiliki kecenderungan elaborasi kurang dengan deskriptor menguraikan gagasan/jawaban secara terperinci. Subyek tidak dapat menguraikan gagasan/jawaban secara terperinci.

\section{PENUTUP}

\section{Simpulan}

Berdasarkan hasil penelitian dan pembahasan yang diperoleh, dapat di ambil suatu kesimpulan kreativitas siswa dalam menyelesaikan soal cerita materi sistem persamaan linear dua variabel siswa kelas VIII sebagai berikut.

1. Siswa kategori tinggi memiliki kecenderungan tahapan kreativitas yang baik dalam menguraikan jawaban secara terperinci. Siswa mampu menyelesaikan masalah dengan prosedur yang runtut, tepat dan benar dalam menyelesaikan soal cerita. 
2. Siswa kategori sedang dengan nilai memiliki kecenderungan tahapan kreativitas yang cukup dalammenguraikan jawaban secara terperinci. Pada umumnya siswa berkemampuan sedang dapat menyelesaikan masalah soal cerita dengan prosedur yang runtut tetapi kurang tepat.

3. Siswa kategori rendah mamiliki kecenderungan tahapan kreativitas yang kurang dalam menguraikan jawaban secara terperinci. Siswa ini umumnya tidak dapat menyelesaikan soal cerita dengan prosedur yang benar sesuai langkah-langkah penyelesaian masalah.

\section{Saran}

Berdasarkan hasil penelitian dan pembahasan, sebagaimana yang telah disimpulkan di atas, peneliti menyarankan:

1. Dengan kemampuan mengajar dan keterampilan yang dimiliki, guru diharap mampu mengajarkan materi dengan pendekatan pembelajaran yang dapat menumbuhkan kreativitas siswa.

2. Siswa harus berlatih menyelesaikan masalah-masalah yang mendorong keingintahuan siswa dalam menyelesaikan masalah untuk menumbuhkan kemampuan berpikir kreatif.

3. Bagi peneliti yang ingin meneliti kreativitas siswa dalam menyelesaikan masalah hendaknya meneliti unsur-unsur kreativitas yang lain yang mungkin belum teridentifikasi untuk megetahui kreativitas siswa sesuai kemampuan yang dimiliki.

\section{DAFTAR PUSTAKA}

Bimo, Walgito. 2004. Pengantar Psikologi Umum. Yogyakarta: ANDI.

Budi, Haryanto. 2011. Teori Pemecahan Masalah Polya.
Herman, Hudojo. 2005. Pengembangan Kurikulum dan Pembelajaran Matematika. Malang: Malang University Press.

Jensen, Eric. 2008. Brain-Based Learning Pembelajaran Berbasis Kemampuan Otak, Cara Baru dalam Pengajaran dan Pelatihan. Yogyakarta: Pustaka Belajar.

La, Moma. 2011. Kemampuan Berpikir Kreatif Matematika.

Mulyasa. 2008. Implementasi Kurikulum Tingkat Satuan Pendidikan Kemandirian Guru dan Kepala Sekolah. Jakarta: PT. Bumi Aksara.

Nana, Sudjana. 2010. Penilaian Hasil Proses Belajar Mengajar. Bandung: PT. REMAJA ROSDAKARYA

Oemar, Hamalik. 2004. Perencanaan Pengajaran Berdasarkan Pendekatan Sistem. Jakarta: PT. Bumi Aksara.

Ormrod, Jeanne Ellis. 2008. Psikologi Pandidikan Membantu Siswa Tumbuh dan Berkembang (Edisi Keenam). Jakarta: Erlangga.

Santrock, John W. 2009. Psikologi Pendidikan (Edisi 3). Jakarta: Salemba Humanika.

Solso, Robert L, Maclin Otto H. dan Maclin Kimberly M. 2007. Psikologi Kognitif (Edisi Kedelapan). Jakarta: Erlangga.

Sugiyono. 2007. Metode Penelitian Kuantitaif Kualitatif dan $R \quad \& \quad D$. Bandung: ALFABETA.

Syamrilaode. 2010. Soal Cerita Matematika.

Syamsu, Yusuf dan Nurihsan, Juntika A. 2010. Landasan Bimbingan \& Konseling. Bandung: PT. REMAJA ROSDAKARYA.

Tim MKPBM Jurusan Pendidikan Matematika. 2001. Strategi Pembelajaran Matematika Kontemporer. Bandung: JICA-UPI

Utami, Munandar. 2009. Pengembangan Kreativitas Anak Berbakat. Jakarta: PT. Rineka Cipta.

Wasilatul, Murtafiah. 2009. Jurnal Pendidikan Matematika (Volume 1, nomor 2). Madiun: IKIP PGRI MADIUN 